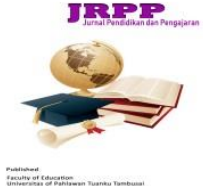

Jurnal Review Pendidikan dan Pengajaran

http://journal.universitaspahlawan.ac.id/index.php/jrpp

Volume 4 Nomor 1, Juni 2021

P-2655-710X e-ISSN 2655-6022
Submitted : 09/06/2021

Reviewed :20/06/2021

Accepted :20/06/2021

Published :29/06/2021

\author{
Muhammad Syahrul \\ Rizal $^{1}$ \\ Mufarizuddin ${ }^{2}$
}

\section{PERSEPSI GURU TERHADAP PEMBELAJARAN DARING DI SEKOLAH DASAR NEGERI 018 LANGGINI BANGKINANG}

\begin{abstract}
ABSTRAK
Penelitian ini memiliki tujuan dalam memaparkan informasi terkait persepsi guru terhadap pembelajaran daring. Informasi didapatkan dari hasil wawancara yang dilakukan dengan enam orang informan yakninya tiga orang wali kelas rendah dan tiga orang wali kelas tinggi. Metode yang digunakan dalam penelitian ini adalah metode penelitian deskriptif kualitatif. Hasil dari penelitian ini mengatakan bahwa pembelajaran daring tidak cocok digunakan pada tingkat sekolah dasar. Karena pada dasarnya pembelajaran anak sekolah dasar masih berpusat kepada guru. Pembelajaran daring membuat tujuan pembelajaran tidak tersampaikan sepenuhnya kepada peserta didik. banyak Masih banyak guru yang kurang pemahaman dalam IPTEK apalagi guru lama, atau guru tradisional sehingga pembelajaran daring menjadi tidak menarik. Masih kurangnya sarana dan prasarana yang mendukung seperti android dan kuota. Adapun dampak dan kendala yang dialami atau dirasakan oleh peserta didik kelas rendah dan kelas tinggi lebih kurang sama. Hal yang membedakannya di kelas rendah masih ada beberapa peserta didik yang masih belum bisa membaca dan menulis, sedangkan dikelas tinggi semua peserta didik sudah bisa membaca dan menulis
\end{abstract}

Kata Kunci: Persepsi, Pembelajaran, Daring

\begin{abstract}
This study aims to provide information related to teachers' perceptions of online learning. Which contains the impacts and constraints of online learning for both low and high classes. Information obtained from the results of interviews conducted with six informants, namely three low-class homeroom teachers and three high-class homeroom teachers. The method used in this research is descriptive qualitative research method. The results of this study indicate that online learning is not suitable for use at the primary school level. Because basically elementary school children's learning is still centered on the teacher. Online learning makes learning objectives not fully conveyed to students. There are still many teachers who lack understanding in science and technology especially old teachers, or traditional teachers so that online learning becomes unattractive. There is still a lack of supporting facilities and infrastructure such as android and quotas. The impacts and constraints experienced or felt by low class and high class students are more or less the same. The thing that distinguishes it in the low class is that there are still some students who are still unable to read and write, while in the high class all students can read and write.
\end{abstract}

Keywords: Perception, Learning, Online

\title{
PENDAHULUAN
}

\section{Latar Belakang}

Menteri Pendidikan dan Kebudayaan Republik Indonesia mengeluarkan Surat Edaran Nomor 4 Tahun 2020 Tentang Pelaksanaan Kebijakan Pendidikan Dalam Masa Darurat Penyebaran Covid-19, dalam Surat Edaran tersebut dijelaskan bahwa proses belajar dilaksanakan di rumah melalui pembelajaran daring/jarak jauh dilaksanakan untuk memberikan

\footnotetext{
${ }^{1}$ Pendidikan Guru Sekolah Dasar, Fakultas Ilmu Pendidikan, Universitas Pahlawan Tuanku Tambusai e-mail : Syahrul.riza192@gmail.com, zuddin.unimed@gmail.com 
pengalaman belajar yang bermakna bagi peserta didik. Belajar di rumah dapat difokuskan pada pendidikan kecakapan hidup antara lain mengenai pandemi Covid-19. Pembelajaran yang dilasanakan pada sekolah dasar juga menggunakan pembelajaran daring/jarak jauh dengan melalui bimbingan orang tua.

Peserta didik dapat berinteraksi dengan guru menggunakan beberapa aplikasi seperti classroom, video converence, telepon atau live chat, zoom maupun melalui whatsapp group. Pembelajaran ini merupakan inovasi pendidikan untuk menjawab tantangan akan ketersediaan sumber belajar yang variatif. Keberhasilan dari suatu model ataupun media pembelajaran tergantung dari karakteristik peserta didiknya. Pembelajaran secara daring merupakan cara baru dalam proses belajar mengajar yang memanfaatkan perangkat elektronik khususnya internet dalam penyampaian belajar.

Pembelajaran daring dapat dilakukan dengan menggabungkan beberapa jenis sumber belajar seperti dokumen, gambar, video, audio dalam pembelajaran. Materi belajar tersebut dapat dimanfaatkan peserta didik dengan melihat atau membaca. Sumber belajar seperti inilah yang menjadi modal utama dalam mengembangkan pembelajaran daring. Karena, jika guru mengemas pembelajaran semenarik mungkin dan sesuai dengan karakteristik peserta didik, maka tujuan pembelajaran dapat tercapai meskipun dalam kegiatan daring. Berdasarkan uraian diatas maka penulis melakukan penelitian berkaitan dengan persepsi guru terhadap pembelajaran daring di SDN 018 Langgini

\section{Rumusan Masalah}

Rumusan masalah yaitu "persepsi guru kelas rendah dan kelas tinggi terhadap pembelajaran daring di SDN 018 Langgini ?

\section{METODE}

\section{Jenis Penelitian}

Penelitian ini menggunakan pendekatan kualitatif dengan desain deskriptif, untuk memberikan gambaran tentang persepsi guru sekolah dasar terhadap pembelajaran daring. Penelitian kualitatif adalah prosedur penelitian yang menghasilkan data deskriptif berupa kata-kata tertulis atau lisan dari orang-orang dan perilaku yang dapat diamati (Slameto, 2015: 72).

\section{Data dan Sumber Data}

Dalam penelitian kualitatif, jenis sumber data yang berupa manusia dalam penelitian pada umumnya sebagai responden (respondent). Posisi sumber data yang berupa manusia (narasumber) sangat penting perannya sebagai individu yang memiliki informasinya. Adapun yang menjadi narasumber dalam penelitian ini adalah 6 orang wali kelas. Data-data yang dikumpulkan dengan cara interview (wawancara), observasi (pengamatan), dan dokumentasi (pengumpulan bukti, pemilihan, pengolahan, dan penyimpanan informasi).

\section{Alat Pengumpul Data dan Keabsahan Data}

Alat yang digunakan untuk mengumpulkan data berupa lembar wawancara yang berisi pertanyaan, lembar dokumentasi dan lainnya sebagai pendukung, Agar data dalam penelitian kualitatif dapat dipertanggungjawabkan sebagai penelitian ilmiah perlu dilakukan uji keabsahan data. Adapun uji keabsahan data yang dapat dilaksanakan: 1. Kredibilitas, 2. Meningkatkan kecermatan dalam penelitian, dan 3. Triangulasi 


\section{Analisis Data}

Dalam penelitian kualitatif, analisis data dilaksanakan sebelum peneliti terjun ke lapangan, selama peneliti mengadakan penelitian di lapangan, sampai dengan pelaporan hasil penelitian. Analisis data dimulai sejak peneliti menentukan fokus penelitian sampai dengan pembuatan laporan penelitian selesai. Analisis data adalah proses mencari dan menyusun secara sistematis data yang diperoleh dari hasil wawancara, catatan lapangan, dan bahan-bahan lain, sehingga dapat mudah dipahami, dan temuannya dapat diinformasikan kepada orang lain. Analisis data dilakukan dengan mengorganisasikan data, menjabarkannya ke dalam unit-unit, melakukan sintesa, menyusun ke dalam pola, memilih mana yang penting dan yang akan dipelajari, dan membuat kesimpulan yang dapat diceritakan kepada orang lain (Sugiyono, 2007: 224). Analisis data dalam penelitian kualitatif, dilakukan pada saat pengumpulan data berlangsung, dan setelah selesai pengumpulan data dalam periode tertentu. Pada saat wawancara, peneliti sudah melakukan analisis terhadap jawaban yang diwawancarai.

\section{HASIL DAN PEMBAHASAN}

\section{Persepsi guru kelas rendah}

Berdasarkan wawancara dengan wali kelas rendah SDN 013 kumantan hampir semua wali kelas rendah mengatakan bahwa pembelajaran daring ini sangat tidak bagus dan memusingkan. wali kelas dua mengungkapkan bahwa pembelajaran saat pandemi covid-19 ini tidak bagus dan membuat kita banyak rugi. Rugi materi dan rugi waktu. Rugi materi maksudnya kita harus membeli kuota lebih dari biasanya. mengatakan bahwa pembelajaran di masa pandemi covid ini sangat kacau, tidak bagus dan memusingkan kepala. Wali kelas satu mengungkapkan bahwa pembelajaran saat pandemi ini sangat memusingkan. Wali kelas lain pun mengungkapkan demikian.

Para wali kelas tiga mengaku bahwa baru kali ini mereka merasakan pembelajaran daring ini. Wali kelas satu mengatakan bahwa pembelajaran daring ini belum cocok dan belum efektif di gunakan dikelas rendah. Begitu wali kelas lain, wali kelas dua dan tiga juga mengatakan hal yang sama. Bahwa pembelajaran daring belum cocok dan belum efektif digunakan di SD. Pembelajaran secara daring juga membuat kurang optimalnya penyampaian materi pembelajaran yang disampaikan kepada peserta didik, sehingga pembelajaran dirasa kurang bermakna bagi peserta didik. Dalam penyampaian materi metode yang digunakan guru juga terbatas, mengingat sulitnya mendapatkan kuota baik orang tua peserta didik maupun guru, pembelajaran hanya dilakukan dalam group di aplikasi yaitu WA. Semua wali kelas mengaku bahwa saat pembelajaran mereka menggunakan aplikasi WA, karena lebih mudah dan lebih murah. Namun meskipun demikian, tidak ada perubahan dalam banyaknya porsi kerja guru dalam menyiapkan proses pembelajaran yang terbaik bagi peserta didik.

\section{Persepsi guru kelas tinggi}

Hasil wawancara dengan wali kelas tinggi mengatakan hal yang sama mengenai pembelajaran daring dengan wali klelas rendah. Wali kelas lima menyatakan bahwa ada sebagian dari orang tua murid tidak menggunakan perangkat-perangkat yang memadai. Hal yang sama juga disampaikan oleh wali kelas empat dan enam bahwa peserta didik ada juga yang tidak memiliki perangkat yang memadai untuk melajar. Dalam pelaksanaan pembelajaran secara daring yang dilakukan di rumah, salah satu keterbatasan dalam pelaksanaan ini ialah sarana dan prasarana yang mendukung, seperti laptop, komputer, handphone, kouta internet dan lain sebagainya. Sarana prasarana menjadi begitu penting dalam mengakomodasi pelaksanaan pembelajaran bagi peserta didik. Pelaksanaan pembelajaran daring dirasa belum optimal dalam penyampaian materi pembelajaran kepada peserta didik, karena biasa belajar di kelas secara face-to-face, sekarang penyampaian materi melalui sebuah wadah. Sehingga pembelajaran menjadi tidak bermakna bagi peserta didik. Salah satu faktornya ialah pembelajaran tidak 
dilakukan dengan tatap muka secara langsung, proses pembelajaran lebih difokuskan dalam bentuk penugasan kepada peserta didik.

Berdasarkan hasil wawancara tantangan bagi guru dalam proses pembelajaran daring ialah penugasan yang diberikan kepada peserta didik tidak sepenuhnya peserta didik yang melakukan, adanya campur tangan orang tua dalam proses penugasan. Namun, ada juga orang tua yang tidak dapat membersamai dirumah, sehingga tidak ada yang dapat membantu dalam mengakomodasi sarana pembelajaran peserta didik. keterbatasan media juga menjadi kendala saat pelaksanaan pembelajaran daring dilaksanakan, masih ada peserta didik dan orang tua yang belum melek teknologi bahkan belum memiliki hp android. Sehingga guru harus memprintkan materi dan tugas yang harus dikerjakan dan mengantarkan ke rumah tiap-tiap peserta didik yang belum memiliki android.

\section{SIMPULAN}

\section{Persepsi Guru Kelas Rendah}

Pembelajaran daring tidak cocok digunakan dikelas rendah. Pembelajaran daring membuat pusing kepala karena tujuan pembelajaran membuat tujuan pembelajaran tidak tercapai secara maksimal. Pembelajaran daring ini sangat banyak kekurangannya dan kendalanya baik bagi guru maupun orang tua dan peserta didik.

\section{Persepsi Guru Kelas Tinggi.}

Begitupun dikelas tinggi pembelajaran daring belum cocok digunakan. Pembelajaran daring membuat waktu habis dan tujuan pembelajaran tidak tercapai dengan baik. Banyak sekali kendala dan kekurangan pembelajaran daring ini baik dari segi jaringan, kuota, android dan sarana lainnya.

\section{DAFTAR PUSTAKA}

Bates, A. W. (1995). Technology, Open Learning And Distance Education. London: Routledge. Bimo, Walgito. (2004). Pengantar Psikologi Umum. Yogyakarta: Andi Offset.

Depdikbud. (1982). Pedoman Umum Ejaan Yang Disempurnakan. Jakarta : Pusat Pembinaan Dan Pengembangan Bahasa - Depdikbud.

Dewi, W.A.F. (2020). Dampak Covid-19 Terhadap Implementasi Pembelajaran Daring Di Sekolah Dasar. Universitas Pahlawan Tuanku Tambusai.

Lofland,dkk. (1984). Analyzing Social Settings. California: Wadsworth Publishing Company.

Moh. Uzer Usman. (2000). Menjadi Guru Profesional. Bandung: Remaja Rosdakarya.

Moleong, Lexy . (2007). Metodologi Penelitian Kualitatif. Edisi Revisi. Bandung : Pt Remaja Rosdakarya.

Mulyasa, E. (2002). Manajemen Berbasis Sekolah. Bandung: Pt. Remaja Rosdakarya.

Permana, G. K, dkk. (2013). Persepsi Peserta Didik dan Guru Terhadap Pelaksanaan

Pembelajaran Berbasis E-Learning Di SMK Negeri 4 Jakarta. State University Of Jakarta Restiyanti, Prasetijo. (2005). Perilaku Konsumen. Yogyakarta :Andi.

Retnoningsih. A. Suharso. (2005). Kamus Besar Bahasa Indonesia, Semarang, Widya Karya Slameto. (2015). Belajar Dan Faktor-Faktor Yang Mempengaruhinya. Jakarta: Rineka Cipta. Sugiyono. (2010). Metode Penelitian Kuantitatif, Kualitatif \& Rnd. Bandung : Alfabeta

Thoha, M. (2003). Perilaku Organisasi Konsep Dasar Dan Aplikasinya. Pt. Raja Grafindo Persada. Jakarta.

Yurianto, dkk. (2020). Pedoman Pencegahan Dan Pengendalian Coronavirus Disease (Covid19) (M. I. Listiana Azizah, Adistikah Aqmarina (Ed). 